\title{
Necrotising fasciitis below the inframammary fold
}

\author{
Yuji Okazaki, ${ }_{1}^{1}$ Toshihisa Ichiba, ${ }^{2}$ Yusuke Higashi ${ }^{1}$
}

${ }^{1}$ Internal medicine, Akiota Hospital, Yamagata-gun, Hiroshima, Japan ${ }^{2}$ Emergency Medicine, Hiroshima City Hiroshima Citizens Hospital, Hiroshima, Japan

Correspondence to Dr Yuji Okazaki: ur8nibhc1@gmail.com

Accepted 30 March 2021

\section{DESCRIPTION}

An 83-year-old woman with dementia presented with fever and acute-onset erythema on her left chest wall under the breast. It appeared 3 hours before arrival to our emergency department. She had no diabetes mellitus and no sign of recent operation. She had been treated with a topical corticosteroid for miliaria under her left breast for several weeks. On examination, her body temperature was $39.9^{\circ}$ with blood pressure of $150 / 74 \mathrm{~mm} \mathrm{Hg}$, heart rate of 88 beats/minute and respiratory rate of 28 breaths/minute. Her white cell count was $12.3 \times 10^{9} / \mathrm{L}$ with a normal $\mathrm{C}$ reactive protein level. Her left chest wall under the breast was swollen with bullae and ecchymoses (figure 1). The skin lesions rapidly extended over a period of 6 hours even after administration of cefazolin. An exploratory incision revealed necrosis of the superficial fascia and thin exudate without purulence (figure 2). We finally diagnosed her with necrotising fasciitis based on these findings, and performed surgical debridement. She was discharged without any further complications.

Necrotising soft-tissue infections (NSTIs) including necrotising fasciitis commonly involve the extremities, perineum and neck, but the chest wall is a rare site of NSTIs. ${ }^{1}$ NSTIs worsen rapidly over a period of several hours and lead to death. Surgical exploration is the only way to establish a diagnosis. ${ }^{2}$ In addition, this patient may not have pain on the chest wall because she had dementia. That could have delayed the diagnosis. It is generally difficult to figure out the accurate complaints of patients with dementia. This condition may lead to a delay in the diagnosis of diseases (ie, necrotising fasciitis) which clinical and physical findings are important to diagnose. Thus, we should carefully evaluate the possibility of NSTIs based on these findings and perform surgical debridement even when atypical NSTIs are suspected. ${ }^{3}$

Another important finding of this case is that not only oral but also topical corticosteroids may be

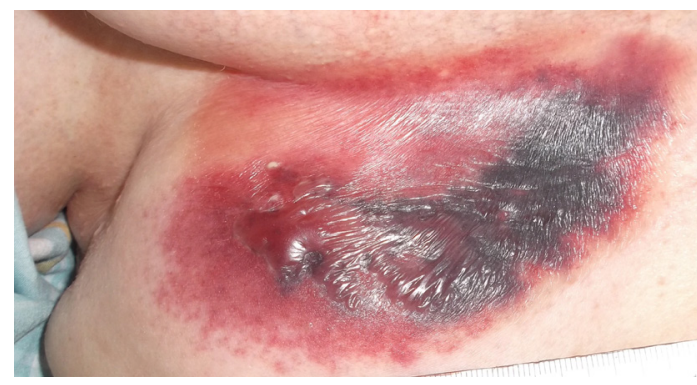

Figure 1 Her left chest wall under the breast was swollen with bullae and ecchymoses 3 hours after the appearance of erythema.

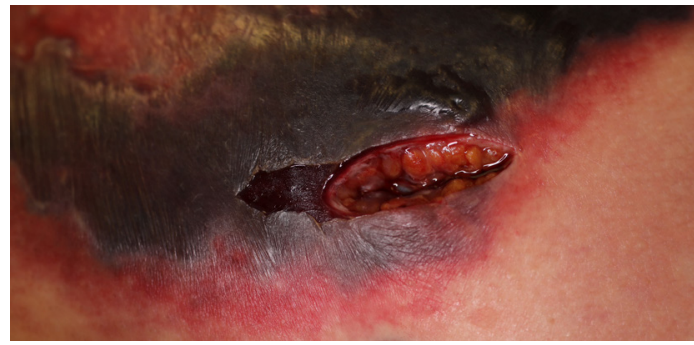

Figure 2 An exploratory incision revealed necrosis of the superficial fascia and thin exudate without purulence.

associated with NSTIs because a topical agent can cause epidermal barrier disturbance. ${ }^{45}$ We should also consider the potential adverse effects of a topical corticosteroid.

\section{Learning points}

- The chest wall is an unusual site for necrotising soft-tissue infections.

- In addition to clinical and physical evaluation, surgical debridement is necessary to confirm necrotising soft-tissue infections even when atypical infections are suspected.

- Not only oral but also topical corticosteroids may be associated with necrotising soft-tissue infections.

Contributors All authors contributed to the development of this manuscript. YO was responsible for literature search and writing of all manuscripts. TI and YH were supervisors.

Funding The authors have not declared a specific grant for this research from any funding agency in the public, commercial or not-for-profit sectors.

Competing interests None declared.

Patient consent for publication Patient/guardian consent was obtained for publication.

Provenance and peer review Not commissioned; externally peer reviewed.

\section{REFERENCES}

1 Schipper P, Tieu BH. Acute chest wall infections: surgical site infections, necrotizing soft tissue infections, and sternoclavicular joint infection. Thorac Surg Clin 2017;27:73-86.

2 Stevens DL, Bisno AL, Chambers HF, et al. Practice guidelines for the diagnosis and management of skin and soft tissue infections: 2014 update by the infectious diseases Society of America. Clin Infect Dis 2014; 59:147-59.

3 Stevens DL, Bryant AE. Necrotizing soft-tissue infections. N Engl J Med 2017;377:2253-65

4 Petitpas F, Blancal J-P, Mateo J, Franck Petitpas J-PB, Farhat I, et al. Factors associated with the mediastinal spread of cervical necrotizing fasciitis. Ann Thorac Surg 2012;93:234-8.

5 Hengge UR, Ruzicka T, Schwartz RA, et al. Adverse effects of topical glucocorticosteroids. J Am Acad Dermatol 2006;54:1-15. 
Images in...

Copyright 2021 BMJ Publishing Group. All rights reserved. For permission to reuse any of this content visit https://www.bmj.com/company/products-services/rights-and-licensing/permissions/

BMJ Case Report Fellows may re-use this article for personal use and teaching without any further permission.

Become a Fellow of BMJ Case Reports today and you can:

- Submit as many cases as you like

- Enjoy fast sympathetic peer review and rapid publication of accepted articles

Access all the published articles

Re-use any of the published material for personal use and teaching without further permission

Customer Service

If you have any further queries about your subscription, please contact our customer services team on +44 (0) 2071111105 or via email at support@bmj.com.

Visit casereports.bmj.com for more articles like this and to become a Fellow 